\title{
TAFSIR WAHBAH AL-Z UHAILI \\ ANALISIS PENDEKATAN, METODOLOGI, DAN CORAK TAFSIR AL-MUNIR TERHADAP AYAT POLIGAMI
}

\author{
Mokhamad Sukron \\ Institut Agama Islam Negeri (IAIN) Purwokerto \\ musyakir.awwy@gmail.com
}

\begin{abstract}
Abstrak
Perkembangan tradisi penafsiran dari masa ke masa menghasilkan produk tafsir dengan berbagai pendekatan, metodologi, dan corak tafsir yang berbeda. Pada zaman sekarang, perbedaan model penafsiran tersebut ditandai dengan rekonstruksi terhadap tradisi penafsiran klasik karena dianggap tidak lagi relevan untuk menjawab persoalan kekinian. Wahbah alZuhaili sebagai salah seorang mufassir kontemporer, menampik hal tersebut dengan menyuguhkan berbagai produk tafsirnya tanpa memutus tradisi penafsiran klasik. Hal tersebut dapat dilihat dari penafsirannya tentang ayat poligami yang komprehensif tanpa meninggalkan tradisi klasik, sehingga sangat relevan dengan kondisi kekinian. Poligami merupakan syari'at Islam sebagai bentuk penghormatan terhadap perempuan, bukan sebagai hal yang tabu dan hina. Sehingga bagi laki-laki, poligami tidak dimaknai sebagai perintah yang melegitimasi kenginan hawa nafsunya, tetapi Islam membolehkan poligami sebagai respon terhadap keadaan darurat ataupun kebutuhan mendesak, seperti istri mengalami kemandulan, di suatu negara populasi perempaun lebih dominan, dan tentang kondisi seksualitas istri yang tidak mampu melayani suami lagi. Walaupun demikian dalam melakukan poligami harus tetap memperhatikan batasan-batasan seperti memiliki kemampuan untuk menafkahi, berlaku adil terhadap seluruh istri, interaksi yang baik.
\end{abstract}

Kata Kunci: Wahbah al-Zuhaili, Tafsir, Poligami

\section{Pendahuluan}

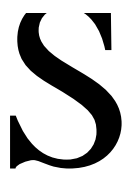

ebagai the way of life bagi umat manusia secara universal, al-Qur'an memperkenalkan diri melalui ayat-ayat yang tersebar di berbagai surah dan menegaskan diri sebagai al-Furqan. Sehingga semua isi al-Qur'an merupakan syariat, asas agama dan pemberi pengertian yang komprehensif dalam menjelaskan dan menetapkan suatu hukum yang argumentatif. ${ }^{1}$ Oleh karena itu, al-Qur'an yang memiliki fungsi yang strategis harus dipahami dengan tepat dan benar.

Upaya memahami al-Qur'an secara tepat dan benar, secara teknisnya dikenal dengan istilah tafsir. Namun perlu diingat bahwa dalam menafsirkan al-Qur'an bukan perkara mudah. Hal itu disebabkan kompliksitas persoalan dan kerumitan yang dikandung di dalamnya. Di mana redaksi-redaksi ayat-ayat al-Qur'an baik lisan maupun tulisan sulit dijangkau maksudnya secara pasti. Meskipun demikian hal itu bukan menjadi bumerang untuk pasrah dan putus asa untuk menafsirkannya terlebih kebutuhan penafsiran al-Qur'an menjadi sangat urgen di setiap zaman. ${ }^{2}$

${ }^{1}$ Wahbah al-Zuhaili, Al-Qur'an dan Paradigma Peradaban, terj. M. Thohir dkk. (Yogyakarta: Dinamika, 1996), 16.

${ }^{2}$ M. Alfatih Suryadilaga dkk., Metodologi Ilmu Tafsir, (Yogyakarta: Teras, 2010), Cet. III, 39-40. 
Dalam perkembangan zaman sekarang banyak sekali muncul upaya pembaharuan dalam tafsir di mana megaproyeknya adalah melakukan rekonstruksi besar-besaran terhadap turats. Pembaharuan penafsiran tersebut, oleh sebagian kalangan akademisi cenderung memutus mata rantai tradisi klasik karena dianggap tidak relevan dan tidak solutif untuk menjawab permasalahan kontemporer. Oleh karena itu, Wahbah al-Zuhaili salah seorang mufassir kontemporer ingin menampik anggapan tersebut dengan menulis karya monumentalnya Tafsir al-Munir fi al-'Aqidah wa al-Syari'ah wa al-Manhaj. Dalam hal ini Wahbah al-Zuhaili masih memegang teguh etos tradisionalis ${ }^{3}$ dan menjaga mata rantai tradisi klasik.

Tulisan ini mencoba menggali khazanah kitab tafsir al-Munir karya Wahbah Zuhaili dari berbagai aspek yang terkandung di dalamnya, dan untuk menganalisis tentang konsistensi Wahbah terhadap tradisi tradisionalis dalam menafsirkan ayat-ayat al-Qur'an, ayat poligami akan dijadikan bahan kajian dalam menggali khazanah tafsir Wahbah al-Zuhaili.

\section{Sketsa Biografi Wahbah al-Zuhaili}

Nama lengkapnya adalah Wahbah bin Musthafa bin Wahbah al-Zuhaili ${ }^{4}$ dengan nama kunyah (panggilan) Abu 'Ubadah. Beliau lahir di desa Dair 'At \}iyyah kecamatan Faiha Provinsi Damaskus Syiria pada tanggal 6 Maret 1932 dari pasangan suami istri yang shaleh dan bertakwa. Ayahnya adalah seorang petani sekaligus penghafal al-Qur'an. Jiwa religiusnya menjadikan ia memiliki impian yang tinggi, yakni memiliki keturunan yang shaleh dan shalehah. Di bawah bimbingan kedua orang tuanya Wahbah al-Zuhaili berhasil menghafal al-Qur'an ketika usianya masih relatif belia. Setelah selesai sekolah pendidikan agama, ia masuk sekolah ibtidaiyyah di kampung halamannya hingga sekolah menengah ke atas.

Selanjutnya, Wahbah al-Zuhaili masuk kuliah di fakultas Syari'ah sekaligus di fakultas Bahasa Arab dan Sastra Universitas Damaskus yang beliau selesaikan keduanya pada tahun 1952 M. Tidak puas dengan apa yang ia raih di dalam negeri, beliau kemudian masuk di fakultas yang sama di Universitas al-Azhar Mesir. Dengan predikat yang sangat cemerlang Wahbah al-Zuhaili selesai kuliahnya pada tahun $1956 .{ }^{5}$ Selain di Universitas al-Azhar, ternyata Wahbah al-Zuhaili masuk kuliah hukum ('ulum al-huquq) di Universitas 'Ain al-Syam Mesir dan lulus pada tahun 1957. ${ }^{6}$ Merasa mantap di

${ }^{3}$ Tradisionalis di sini dimaksudkan kepada sebuah tradisi yang masih menjaga warisan masa lalu dan melihat ilmu sebagai sebuah "konservasi" daripada reasi dan inovasi, di mana seseorang sangat terlatih untuk mentransmisikan pengetahuan. Lihat Robinson, Islamic Historiography (Cambridge: Cambridge University Press, 2006), 85-92.

${ }^{4}$ Al-Zuhaili adalah nama yang dinisbatkan kepada kota kelahiran ayahnya yang bernama Zahlah di wilayah Libanon. Lihat. Louis Ma'lûf, Kamus al-Munjid, (Beirût: al-Maktabah al-Syarqiyyah, 1986), bab al-A'lam, 320.

${ }^{5}$ Baihaki, Studi Tafsir al-Munir Karya Wahbah al-Zuhaili dan Contoh Penafsirannya tentang Pernikahan Beda Agama, Journal Analisis, Vol. XVI, No. 1, Juni 2016, 128-129.

${ }^{6}$ Zamakhsyari Abdul Madjid, Metodologi Penafsiran Ayat-Ayat Hukum Dalam Tafsir Al-Munir, (Jakarta: Disertasi Sekolah Pasca Sarjana Universitas Islam Negeri (UIN) Syarif Hidayatullah, 2009), 110. 
Universitas al-Azhar beliau melanjutkan strata duanya di sana dan lulus pada tahun 1959 M. Pada tahun 1963, Wahbah berhasil meraih gelar doktoralnya di universitas yang sama.

Selepas pendidikan strata tiganya di Universitas al-Azhar Mesir, Wahbah al-Zuhaili mengabdikan dirinya sebagai dosen di fakultas Syari'ah Universitas Damaskus. Karena keilmuannya yang sangat tinggi, tidak lama kemudian diangkat menjadi pembantu dekan di fakultas yang sama. Jabatan sebagai pembantu dekan ia pegang tidak lama, hal itu dikarenakan ia diangkat menjadi dekan sekaligus ketua jurusan fiqh al-Islami. Puncak karirnya di Universitas Damaskus adalah sebagai guru besar dalam bidang hukum Islam.

Wahbah al-Zuhaili dibesarkan di lingkungan yang masyarakat dan para ulamanya menganut madzhab Hanafi maka pola pemikirannya pun mengikuti madzhab Hanafi. Walaupun demikian, dalam pengembangan dakwah dan pemikirannya Wahbah al-Zuhaili tidak mengedepankan madzhab yang beliau anut, justru beliau bersikap netral dan proporsional serta menghargai pendapat-pendapat dari madzhab yang berbeda. Hal itu bisa kita lihat dari bentuk penafsiran ayat-ayat al-Qur'an yang beliau kupas. Dalam prosesnya, beliau akhirnya menjadi salah satu pakar perbandingan madzhab fikih kontemporer. Wahbah al-Zuhaili dianugerahi umur 83 tahun (Masehi), tepat tanggal 8 Agustus 2015 beliau pulang ke rahmatullah.

Wahbah al-Zuhaili merupakan pemuda yang sangat energik dalam bidang keilmuan Islam. Hal itu terbukti dengan berbagai karya ilmiahnya baik artikel maupun makalah yang cukup banyak, yakni sekitar 500 tema. Tidak hanya itu, beliau juga telah menulis 133 buah buku sebelum mamasuki usia 30 tahun. Beliau memulai tulisannya dari tematema keagamaan seperti ushul fiqh, kritik hadis dan tafsir al-Qur'an. Selanjutnya beliau menulis beberapa tokoh sahabat Nabi seperti Usamah bin Zaid dan Ubadah bin al-Samit, tokoh tabi'in seperti Sai'd bin al-Musayyab dan tokoh Islam terkemuka seperti Umar bin Abdul Aziz. ${ }^{7}$ Di antara karya-karya yang masyhur adalah sebagai berikut:

1. Al-Fiqh al-Islami wa Adillatuhu, (1997) dalam 9 jilid tebal. karya kemudian disempurnakan beberapa jilid dan diberi nama baru Mausu'at al-Fiqh al-Islami.

2. Usul al-Fiqh al-Islami, dalam 2 jilid besar.

3. Al-Wasit fi Usul al-Fiqh, Universitas Damaskus, 1966.

4. Al-Fiqh al-Islāmi fi Uslub al-Jadid, Maktabah al-Haditsah, Damaskus, 1967.

5. Fiqh al-Mawāris fi al-Syari'āt al-Islāmiyyah, Dar al-Fikr, Damaskus, 1987.

6. Al-Qur'ān al-Karim; Bunyātuhu al-Tasyri'iyyah aw Khasā'isuhu al-Hasāriyah, Dar al-Fikr, Damaskus, 1993.

7. Al-Asas wa al-Masadir al-Ijtihād al-Musytarikah Bayna al-Sunnah wa al-Syi'ah, Dar al-Maktabi, Damaskus, 1996.

${ }^{7}$ Badi'u al-Sayyid al-Lahm, Wahbah al-Zuhaili: al- 'Alim wa al-Faqih wa al Mufassir, (Damaskus: Dâr al-Qalam, 2001), 46. Lihat juga; Muhammad 'Arif Ahmad Fa'ri', Manhaj Wahbah al-Zuhaili fi alTafsir li al-Qur'an al-Karim: Tafsir al-Munir, (Karya Thesis di Universitas Alu al-Bait, 1998), 16-25. 
8. Tafsir al-Munir fi al- 'Aqidah wa al-Shari 'ah wa al-Manhaj, terdiri dari 16 jilid. Dar al-Fikr, Damaskus, 1991.

9. Tafsir al-Wajiz merupakan ringkasan dari Tafsir al-Munir.

10. Tafsir al-Wasit dalam 3 jilid tebal, dan karya-karya lainnya.

\section{Guru dan Murid Wahbah al-Zuhaili}

Sebagai seorang akademisi sekaligus ulama tentu harus memiliki sanad keilmuannya. Hal itu dibuktikan dengan adanya guru-guru yang mampu mencetak ulama sekaliber Wahbah al-Zuhaili. Di antara guru-gurunya adalah Abdurrazaq al-Hamasi (w. 1969 M), Muhammad Hasyim al-Khathib al-Syafi'i (w. 1958 M), Mahmud Yasin (w. 1948 M), Hasan Jankah, S \}adiq Jankah al-Maidani dan Muhammad S \}alih Farfur (w. 1986 M). Mereka semua adalah guru-guru Wahbah al-Zuhaili ketika di Damaskus. Sedangkan guru-gurunya ketika di Kairo adalah Muhammad Salt\}ut\} (w. 1963 M), Abdurrahman Taj, Isa Manun, Mustafa Abdul Khaliq, Abdul Ghani, dan masih banyak lagi.

Sebagai ulama dan tokoh besar Islam yang memiliki samudera ilmu tentu Wahbah al-Zuhaili memiliki murid yang sangat banyak terlebih beliau mengajar di berbagai tempat baik sebagai dosen maupun di majelis ta'lim masjid-masjid atau bahkan di televisi. Di antara murid-muridnya yang terkenal adalah Muhammad Faruq Hamdan, Muhammad Na'im Yasin, 'Abdul al-Satar Abu Ghadah, 'Abd al-Latif Farfur, Muhammad Abu Lail, putranya sendiri; Muhammad al-Zuhaili dan masih banyak lagi. ${ }^{8}$

\section{Tafsir Al-Munir}

Tafsir ini diberi judul al-Tafsir al-Munir fì al-'Aqidah wa al-Shari'ah wa alManhaj, diterbitkan pertama kali pada tahun 1991 oleh Dar al-Fikr al-Mu'ashir, Beirut, Libanon. Tafsir al-Munir ditulis ketika al-Zuhaili menjadi Visitting Professor di Kuwait, dalam kurun waktu 5 tahun tanpa istirahat kecuali makan dan shalat. ${ }^{9}$ Ketika al-Zuhaili selesai menulis kitab tafsirnya, sebelum dicetak, beliau menyerahkannya kepada pelajar setingkat sekolah menengah untuk membacanya. Hal itu beliau lakukan agar tahu apakah bahasa yang digunakan mudah dicerna atau tidak oleh para pelajar.

Tafsir al-Munir merupakan ensiklopedi al-Qur'an yang mencakup kurang lebih 9000 halaman, 30 juz dalam 16 jilid. Setiap satu jilid mencakup dua juz tafsir al-Qur'an kecuali beberapa jilid terakhir dengan memulai dan mengakhiri satu surah. Kemudian pada jilid terakhir hanya berisi indeks tentang tema-tema dan istilah-istilah yang ada dalam tafsir al-Munir lengkap dengan informasi juz, jilid dan halamannya. ${ }^{10}$ Motif yang

${ }^{8}$ Baihaki, Studi Tafsir al-Munir Karya Wahbah al-Zuhaili dan Contoh Penafsirannya tentang Pernikahan Beda Agama, 130.

${ }^{9}$ Perkuliahan Prof. Dr. Ahmad Thib Raya, MA. dalam mata kuliah Quranic Exegesis Method UIN Syarif Hidayatullah pada tanggal 20 Desember 2017.

${ }^{10}$ Muhammad 'Arif Ahmad Fa'ri', Manhaj Wahbah al-Zuhaili fi al-Tafsir li al-Qur'an al-Karim: Tafsir al-Munir, 29-30. 
mendasari al-Zuhaili menulis tafsir al-Munir ini adalah sebagai bentuk kekaguman dan kecintaannya terhadap al-Qur'an. Hal tersebut termaktub dalam mukadimah tafsirnya dengan menegaskan bahwa al-Qur'an sejatinya adalah satu-satunya kitab yang paling sempurna yang dapat memberikan inspirasi dalam banyak hal, al-Qur'an sebagai rujukan utama memiliki sifat yang tidak pernah kering akan informasi untuk segala bidang keilmuan maupun bidang sosial. Menurut al-Zuhaili, al-Qur'an mempunyai ikatan yang erat dengan kebutuhan kontemporer baik dalam kebudayaan maupun pendidikan. ${ }^{11}$

Al-Zuhaili juga memberikan penegasan bahwa gaya bahasa level tinggi yang dimiliki al-Qur'an menjadikannya mampu mengupas ilmu pengetahuan yang sangat luas dan fokus dalam tujuan dan targetnya, yakni sebagai petunjuk sekaligus the way of life yang bebas dari segala penyimpangannya. Menurut beliau, al-Qur'an juga memiliki pesan-pesan yang merefleksikan nalar berpikir yang ekploratif dalam menggali potensi manusia di jalan kebenaran sebagai wujud kepeduliannya memerangi kebodohan dan keterbelakangan. Sehingga tepat sekali al-Qur'an mengklaim dirinya sebagai sumber ilmu pengetahuan dalam segala disiplin ilmu pengetahuan dari dahulu hingga sekarang bahkan yang akan datang. ${ }^{12}$

Sebelum memulai tafsir al-Qur'an, al-Zuhaili memberikan penjelasan tentang beberapa definisi penting yang berkaiitan dengan ulum al-Qur'an seperti definisi alQur'an sendiri, bagaimana ayat al-Qur'an turun, metode pengumpulannya, metode penulisan al-Qur'an, rasm Uthmani, tujuh huruf dan tujuh qira'at, sisi mu'jizat al-Qur'an yang berbeda-beda, Bahasa al-Qur'an, Terjemah al-Qur'an dan hukumnya, huruf-huruf al-muqatta'ah pada awal surah beserta pendapat para ulama dan yang terakhir adalah membahas tentang kesesuaian, isti'arah (perumpamaan), majaz dan penulisan alQur'an. ${ }^{13}$

Secara garis besar bahasannya meliputi tema-tema besar, seperti pengertian alQur'an dan nama-nama lain dari kitab suci ini, cara turunnya al-Qur'an, tentang ayat-ayat makki dan madani, ayat-ayat yang pertama dan yang terakhir turun; tahapan-tahapan kodifikasi al-Qur'an dan sebagainya, yang lazim dalam kajian ulum al-Qur'an. Semua ini disajikan dengan bahasa yang mudah dipahami, dengan menyertakan pendapat para ulama yang $m u$ 'tabar dengan uraian yang singkat dan jelas.

\section{Pendekatan dalam Tafsir al-Munir}

Jika kita cermati, tafsir ini menggunakan model penafsiran yang memadukan antara penafsiran bi al-ma'tsur (periwayatan) dan bi al-ra'yi (penalaran dan ijtihad). Hal itu terlihat ketika al-Zuhaili mencoba menuangkan idenya dengan mengomentari riwayat-

${ }^{11}$ Wahbah al-Zuhaili, Al-Tafsir al-Munir fì al-'Aqidah wa al-Shari 'ah wa al-Manhaj, (Beirut: Dâr al-Fikr, 1991), Juz. I, 5.

${ }^{12}$ Ibid, 6.

${ }^{13}$ Muhammad 'Arif Ahmad Fa'ri', Manhaj Wahbah al-Zuhaili fi al-Tafsir li al-Qur'an al-Karim: Tafsir al-Munir, 29-30. 
riwayat yang ia paparkan dan menggali hukum yang terkandung di dalamnya. ${ }^{14}$ Meskipun, sesungguhnya masih terdapat perbedaan antara batasan ma'tsur dan ra'yu yang sering kali bercampur satu sama lain atau bahkan saling melengkapi.

Tafsir bi al-ma'tsur yang diaplikasikan oleh al-Zuhiali lebih mementingkan keringkasan, yakni riwayat-riwayat yang dijadikan rujukan dalam tafsirnya adalah riwayat yang paling benar saja, yang dinukil dari kitab-kitab tafsir klasik sehingga hampir tidak dijumpai perdebatan mengenai kualitas sanad antara riwayat-riwayat yang beragam dalam menjelaskan makna ayat. Tafsir bi al-ra'yi yang diaplikasikan al-Zuhaili ketika menjelaskan penafsiran suatu ayat, yakni penalaran dan ijtihadnya, terlihat tidak mendapatkan porsi yang terlalu besar namun masih menempati porsi yang signifikan di bagian lain dalam menjelaskan kandungan ayat. Hal itu disebabkan adanya pemisahan antara penafsiran ayat (al-tafsir wa al-bayan), yang merupakan pemahaman lahiriyah ayat, dengan penjelasan kandungan ayat (al-fiqh al-hayat), yang merupakan pemahaman terhadap pesan-pesan al-Qur'an yang berhubungan dengan isu-isu yang berkembang di dalam masyarakat, baik dimensi hukum maupun persoalan lainnya.

\section{Metodologi dan Langkah - Langkahnya dalam Tafsir al-Munir}

Terkait metodologi yang digunakan al-Zuhaili dalam menafsirkan ayat-ayat alQur'an lebih cenderung mengambil pola kontemporer, yakni metode tahlili (analitik) ${ }^{15}$ walaupun sedikit mengkombinasikan metode semi maudu' $i$ (tematik). ${ }^{16}$ Adapun langkahlangkah yang ditempuh al-Zuh \}aili> dalam tafsirnya pun disusun sebagai berikut:

1. Menafsirkan ayat-ayat al-Qur'an sesuai urutan mushaf.

2. Terlebih dahulu menjelaskan unsur-unsur yang terkait dengan segala hal yang dikandung oleh ayat, seperti aspek-aspek kebahasaan meliputi i'rab, balaghah, makna kosa kata, asbab al-nuzul dan munasabat (korelasi suatu ayat dengan ayat sebelumnya). Dalam menjelaskan aspek-aspek kebahasaannya al-Zuhaili selalu menyebutkan kitab-kitab rujukannya seperti kitab al-Bayan fi Gharib I'rab alQur'an karya Abu al-Barakat bin al-Anbari, kitab Shafwah al-Tafasir karya Muhammad 'Ali al-Shabuni, kitab tafsir al-Kasysyaf karangan Imam Zamakhsyari dan tafsir al-Qurtubi. ${ }^{17}$

${ }^{14}$ Muhammad Husain al-Zahabi, al-Tafsir wa al-Mufassirun, (Kairo: Dâr al-Hadits, 2005), Juz. 1, 128.

15 Metode tahlili (analitis) adalah metode tafsir yang bermaksud menjelaskan ayat-ayat al-Qur'an dari seluruh aspeknya. Lihat 'Abd al-Hayy al-Farmawi, al-Bidayah fi al-Tafsir al-Maudu'i, (Kairo: alHadharah al-'Arabiyah, 1977), Cet. II, 24.

${ }^{16}$ Tafsir al-Maudu'i adalah tafsir ayat-ayat al-Qur'an yang memiliki tema dan tujuan satu dengan pembahasan secara detail, menjaga urutan ayat sesuai urutan mush \}af, melihat asbab al-nuzul, sunnah alnabawiyah dan pendapat ulama salaf terkait ayat yang ditafsiri. Lihat Ahmad bin 'Abdullah al-Zahrani, alTafsir al-Maud\}'i'i li al-Qur'an al-Karim wa Namadziji minhu, (Madinah: Universitas Islamiyah Madinah, $1413 \mathrm{H}), 12$.

${ }^{17}$ Mani' 'Abd Halim Mahmud, Metodologi Tafsir: Kajian Komprehensif Metode Para Ahli Tafsir, terj. Syahdianor dan Faisal Saleh (Jakarta: Raja Grafindo Persada, 2006), 226. Lihat juga Ahmad bin Muhammad al-Syarqawi, Manahij al-Mufassirin, (Riyadh: Maktabat al-Rusyd, 1424 H), 216. 
3. Ketika menyebutkan asabab al-nuzul ayat, al-Zuhaili meyakinkan bahwa riwayatriwayat yang ditampilkan adalah yang paling sahih, tanpa menguraikan perselisihan pendapat dalam riwayat-riwayat tersebut. Dalam hal ini, yang sering dijadikan rujukan untuk menerangkan asabab al-nuzul ayat adalah kitab tafsir al-Thabari dan al-Qurtubi, di samping juga kitab Asbab al-Nuzul karya al-Wahidi.

4. Ketika menjelasan korelasi (munasabah) ayat, al-Zuhaili bersikap sangat moderat. Adakalanya poin ini digandengkan dengan sebab turun ayat dalam satu sub judul yang sama untuk mendapatkan pemahaman yang lebih dekat, seperti pada almunasabah wa asabab al-nuzul kelompok ayat al-Baqarah:116-118. Korelasi ayat ini menyatakan bahwa ayat sebelumnya telah menunjukkan anggapan orang-orang Yahudi tentang surga yang khusus dijadikan bagi mereka. Pada ayat ini pula mereka mengklaim bahwa 'Uzair adalah anak Allah. Hal ini berbeda dengan pandangan orang-orang Nasrani yang menganggap bahwa 'Isa adalah anak Allah. Berbeda lagi dengan kaum Musyrik, yang mengklaim bahwa malaikatlah yang merupakan anakanak perempuan Allah. Akhirnya, turunlah ayat ini untuk membantah segala tuduhan tersebut. ${ }^{18}$

5. Dalam uraian tafsirnya, al-Zuhaili lebih cenderung menjelaskan isi kandungan setiap surah secara global dan mendiskusikan alasan penamaan sebuah surah dan keutamaannya (fadilah). Misalnya dalam membahas surah al-Fatihah, al-Zuhaili menegaskan bahwa ia adalah surah makkiyah yang berjumlah 7 (tujuh) ayat dan diturunkan setelah surah al-Mudatstsir. Kandungan surah ini secara global berkenaan dengan makna (kandungan) al-Qur'an secara keseluruhan, mencakup pokok-pokok (ajaran) agama dan cabang-cabangnya yang meliputi akidah, ibadah, penetapan hukum dan keimanan kepada hari kebangkitan serta sifat-sifat dan namanama Allah al-husna, pemurnian akidah, ibadah dan doa, petunjuk dalam mencari hidayah ke agama yang benar dan jalan yang lurus, dan juga agar dijauhkan dari jalan orang-orang yang menyimpang dari hidayah Allah Swt. ${ }^{19}$

6. Al-Zuhaili juga berusaha keras untuk menerapkan metode tematik dengan menafsirkan ayat-ayat yang berbeda namun masih memiliki satu tema, seperti jihad, hudud, warisan, hukum pernikahan, riba dan khamr. ${ }^{20}$ Dalam hal ini, metode semi tematik beliau aplikasikan dengan membagi kelompok-kelompok ayat al-Qur'an (dalam satu surah) dan menetapkan satu tema yang jelas yang mewakili kandungan ayat.

7. Dalam menjabarkan penafsiran suatu ayat al-Zuhaili menguraikannya secara luas dengan memberikan penekanan pada hal-hal yang sering menjadi perdebatan di kalangan ulama dalam bagian yang diberi nama "al-Tafsir wa al-bayan."

8. Al-Zuhaili dalam menguraikan hukum-hukum yang terkandung di dalam pemahaman ayat ataupun penjelasan tentang kandungan ayat yang bersifat kekinian yang menyertai penafsiran ayat dalam bagian yang diberi nama "fiqh al-hayah aw

\footnotetext{
${ }^{18}$ Wahbah al-Zuhaili, Al-Tafsir al-Munir fì al- 'Aqidah wa al-Shari 'ah wa al-Manhaj, jld. I, 286.

${ }^{19} \mathrm{Ibid}, 53$.

${ }^{20}$ Ibid, 9.
} 
al-ahkam". Sebagaimana cakupan isinya, bagian ini adakalanya menguraikan aspek hukum yang terkandung di dalam ayat sesuai dengan porsi kajian yang lazim di kalangan ulama, tetapi jika terdapat banyak perdebatan, maka ia akan diuraikan secara khusus, seperti dalam menjelaskan ayat tentang ketentuan nasakh (alBaqarah/2: 106-108) dengan uraian yang memadai dan mendalam. ${ }^{21}$ Namun, pembahasan bisa saja berisi uraian mengenai hal-hal lain yang dapat diintisarikan dari pemahaman ayat jika kandungan ayat tidak memiliki muatan hukum tertentu, tetapi hanya perlu pemahaman ayat dalam konteks kekinian.

\section{Corak dalam Tafsir al-Munir}

Dilihat dari langkah-langkah yang telah diuraikan di atas, al-Zuhaili kelihatannya masih dipengaruhi oleh latar belakang keilmuannya, yaitu hukum Islam dan filsafat hukum, dalam diskusinya mengenai makna ayat-ayat al-Qur'an. Di sini dapat dilihat bahwa Tafsir al-Munir memiliki corak fikih yang kental. Selain dari corak fikih, tafsir ini juga kental dengan nuansa sastra, budaya dan kemasyarakatan (al-adab al-ijtima 'i), yaitu suatu corak tafsir yang menjelaskan petunjuk-petunjuk al-Qur'an yang terkait langsung dengan kehidupan masyarakat serta usaha-usaha untuk menanggulangi masalah-masalah tersebut dengan penjelasan yang indah namun mudah dipahami. ${ }^{22}$

Bagian yang diberi sub judul fiqh al-hayah aw al-ahkam berperan dalam membahas hal-hal yang belum seutuhnya tuntas dibahas dalam penafsiran ayat, atau adakalanya juga persoalan-persoalan yang diangkat merupakan persoalan yang masih menimbulkan polemik (Syubhat) di kalangan umat Islam dan bahkan membicarakan hukum dan perbedaan pendapat (Ikhtilaf) Fuqaha di dalamnya. Dengan demikian, permasalahanpermasalahan yang dikaji tersebut mendapat kejelasan. Bahkan, tidak jarang al-Zuhaili menarik suatu kesimpulan atau nasehat sebagai pelajaran dari penjelasan-penjelasannya.

Apa yang dapat ditegaskan di sini adalah bahwa selain memperlihatkan pengaruh dari latar belakang keilmuan al-Zuhaili dalam bidang ilmu hukum Islam dan filsafat hukum yang telah ditekuni selama lebih dari tiga puluh tahun, ia juga dimaksud agar mufasir lebih leluasa dalam menjelaskan maksud dan cakupan makna ayat-ayat al-Qur'an tanpa harus "memaksakan" ijtihad pribadinya ke dalam pemahaman ayat al-Qur'an yangboleh jadi bukan merupakan maksud dari pesan-pesan Kalam Ilahi yang sebenarnya. Hal ini, tidak dapat disangkal, merupakan salah satu ciri khas al-Zuhaili, di mana ia sangat menonjolkan kehati-hatian dan berupaya membebaskan al-Qur'an dari penafsiran yang mengikuti hawa nafsu.

Dengan kata lain, dalam karyanya al-Tafsir al-Munir fí al- 'Aqidah wa al-Shari 'ah wa al-Manhaj, Al-Zuhaili menekankan bahwa tujuan utama dari karya ini adalah mengembalikan pemahaman yang utuh tentang ajaran Ilahi agar dapat dijadikan pedoman

21 Ibid, 259-268.

22 Pengertian corak ini lihat Quraish Shihab, Membumikan al-Qur'an: Fungsi dan Peran Wahyu dalam Kehidupan Masyarakat, (Bandung: Mizan, 1996), Cet. XXIII, 108. 
bagi kaum Muslim sebagai dasar pijakan dalam berakidah yang benar, panduan dalam penetapan berbagai hukum dan sebagai tuntunan ke jalan lurus yang diridai oleh Allah Swt. Di samping itu, kehati-hatian al-Zuhaili dalam menjelaskan penafsiran ayat menjadi poin positif dan menghindarkan para pembaca dari kekhawatiran akan mendapatkan penjelasan yang subjektif.

\section{Ayat Poligami Perspektif Wahbah al-Zuhaili}

Poligami menjadi sebuah fonomena yang mendapat perhatian lebih oleh para perempuan di Indonesia. Ketika ada obrolan tentang ta'adud al-zaujah (poligami) hampir sebagian perempuan menolaknya atau secara diplomatisnya mereka mengatakan "poligami boleh asal bukan suami saya". Hal tersebut terkesan pembahasan poligami yang terdapat di dalam al-Qur' an hadir sebagai perintah yang tidak memberikan maslahat bagi kaum perempuan, karena dipahami dan dimaknai tidak komprehensip. Penafsiran tentang ayat poligami harus dipahami secara utuh dan relevan dengan kondisi masa sekarang, sebagaimana yang dilakukan oleh al-Zuhaili dalam menafsirkan ayat-ayat poligami.

Di dalam surat al-Nisa ayat 3 dijelaskan tentang poligami yang berbunyi:

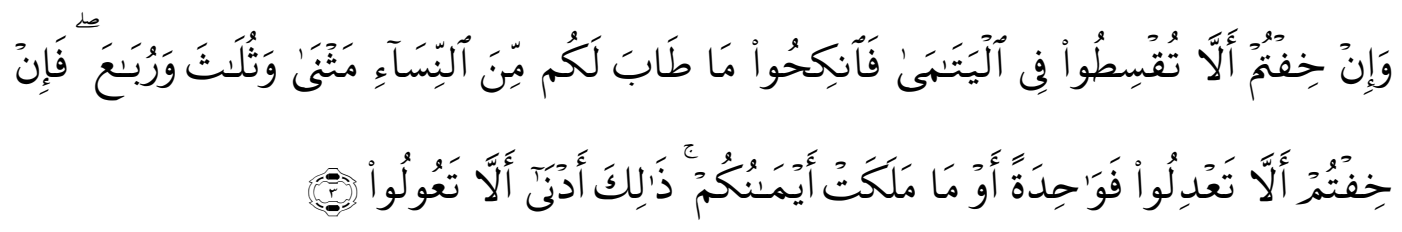

"dan jika kamu takut tidak akan dapat berlaku adil terhadap (hak-hak) perempuan yang yatim (bilamana kamu mengawininya), maka kawinilah wanita-wanita (lain) yang kamu senangi: dua, tiga atau empat. Kemudian, jika kamu takut tidak akan dapat berlaku adil, maka (kawinilah) seorang saja atau budak-budak yang kamu miliki. Yang demikian itu adalah lebih dekat kepada tidak berbuat aniaya." 23 (QS. Al-Nisa' [4]: 3

\section{Tafsir dan Bayan Surat Al-Nisa'Ayat 3-4}

Al-Zuhaili menjelaskan tafsir surat al-Nisa' ayat 3-4 bahwa dua ayat ini memiliki batasan tema mengenai menikahi perempuan bukan yatim yang menjadi tanggung jawab seseorang atau bersikap adil terhadap istri-istri, jika tidak mampu berbuat adil maka lebih baik memiliki satu istri saja. Beliau juga menjelaskan makna "al-Khauf" dalam ayat ini, bahwa yang dimaksud kalimat "al-khauf" adalah memahami dan merasa akan berbuat kezaliman dengan menikahi anak yatim dengan tidak memberinya mahar atau memakan hartanya maka jangan menikahi anak yatim tersebut dan menikah lah dengan perempuan lain satu, dua, tiga atau empat akan tetapi jangan melebihi jumlah tersebut. Sebab jumlah

${ }^{23}$ Ahmad Lutfi Fathullah, Al-Qur'an al-Hadi, (Jakarta: Pusat Kajian Hadis, 2013), dalam bentuk aplikasi versi 1.5.5. 
terakhir (empat) merupakan tingkatan tertinggi kehalalannya dengan disertai bertindak adil. Begitu juga menjelaskan kalimat fi'il amar "fankihu" menunjukkan kebolehan menikah dengan jumlah tersebut. Artinya, menikah dengan bilangan dua, tiga dan empat merupakan hal yang boleh bukan wajib. ${ }^{24}$

Kaitannya dengan definisi 'adil, menurut al-Zuhaili, merupakan hal yang sulit untuk direalisasikan namun masih bisa diupayakan. Beliau kemudian mengutp firman Allah swt dalam surat al-Nisa' ayat 129:

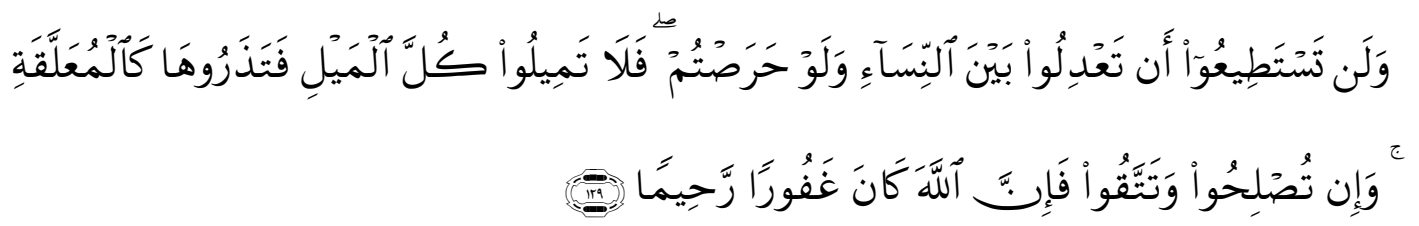

"dan kamu sekali-kali tidak akan dapat Berlaku adil di antara isteri-isteri(mu), walaupun kamu sangat ingin berbuat demikian, karena itu janganlah kamu terlalu cenderung (kepada yang kamu cintai), sehingga kamu biarkan yang lain terkatungkatung. dan jika kamu Mengadakan perbaikan dan memelihara diri (dari kecurangan), Maka Sesungguhnya Allah Maha Pengampun lagi Maha Penyayang. "25 (QS. Al-Nisa'[4]: 129)

Ayat tersebut, menurut al-Zuhaili, memberikan indikasi bahwa berlaku adil tergantung dengan hati seorang suami. Jika seorang suami mampu mengendalikan kecenderungan dalam segala hal terhadap istri-istrinya maka ia dapat dikatakan telah berlaku adil namun jika sebaliknya maka ia telah berlaku tidak adil. ${ }^{26}$ Sebagian besar masyarakat memandang bahwa ayat tersebut merupakan indikasi ketidakmampuan seseorang berbuat adil adalah tidak tepat. Karena jika pandangan itu dibenarkan maka alQur'an tidak akan menganjurkan untuk menikahi perempuan dua, tiga dan empat. Namun, al-Zuhaili memberikan anjuran dengan mengutip tafsirnya imam al-Syafi'i terkait tafsir ayat tersebut, bahwa kalimat "an la ta'ulu" maksudnya adalah jangan memperbanyak keturunan (dengan menikahi banyak istri). Al-Zuhaili juga mengutip tafsirannya al-Kisa'i, al-Asma'i dan al-Azhari terkait ayat tersebut dengan ucapan ahli fusha bahasa Arab "'ala ya'ul: idza kathurat 'ayaluhu."

Ringkasnya, untuk menjauhi kehancuran maka menikah satu istri saja. Keadilan yang dimaksud dalam ayat tersebut adalah memiliki dua makna, pertama adalah keadilan materi seperti pembagian giliran menginap, kesetaraan nafkah kehidupan meliputi makan, minum, pakaian dan tempat tinggal. Kedua adalah keadilan maknawi, yakni

${ }^{24}$ Wahbah al-Zuhaili, Al-Tafsir al-Munir fì al- 'Aqidah wa al-Shari' 'ah wa al-Manhaj, jld. 4, 234235.

${ }^{25}$ Ahmad Lutfi Fathullah, Al-Qur'an al-Hadi, (Jakarta: Pusat Kajian Hadis, 2013), dalam bentuk aplikasi versi 1.5.5.

${ }^{26}$ Wahbah al-Zuhaili, Al-Tafsir al-Munir fì al- 'Aqidah wa al-Shari 'ah wa al-Manhaj, jld. 4, 235. 
kecenderungan hati yang perlu disetarakan terhadap istri-istrinya, sebagaimana doa Rasulullah saw. ketika hatinya condong terhadap 'Aisyah:

$$
\text { اللهم هذا قسمي فيما أملك، فلا نؤاخذني فيما لا أملك }
$$

Sebagai bentuk mohon perlindungan kepada Allah swt. dari siksa-Nya, sebagaimana sabda beliau yang berbunyi:

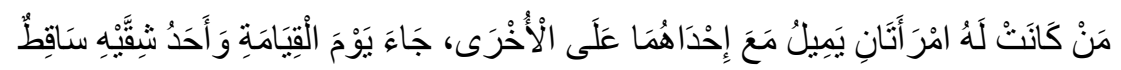

"Barang siapa memiliki dua istri dan ia lebih condong ke salah satu istrinya maka pada hari kiamat nanti ia datang dengan salah satu tubuhnya terbelah jatuh ke bawah. "27

Ketiga adalah ketika merasa takut tidak berbuat adil terhadap istri-istrinya maka haram hukumnya poligami. Keempat, adalah ketika menikah seharusnya memberikan mahar sesuai dengan keinginan dan kesukaan calon istri untuk menunjukkan rasa cinta kasih dan memuliakan perempuan. ${ }^{28}$

\section{Fiqh al-Hayah wa al-ahkam}

1. Terkait dengan ayat wain khiftum an la ta'dilu

a. Kewajiban berbuat adil baik dalam menafkahkan harta anak yatim maupun nafkah terhadap istri-istri dan bukan perempuan yatim.

b. Larangan menikahi anak yatim dikarenakan ditakutkan tidak bisa berbuat adil terlebih tidak memberinya mahar.

c. Imam Abu Hanifah menjadikan ayat ini dalil dibolehkannya menikahi anak yatim sebelum baligh berbeda dengan imam Malik, imam al-Syafi'i dan mayoritas ulama.

d. Tafsir 'Aisyah terkait ayat ini memberikan indikasi bahwa mahar adalah wajib.

e. Bolehnya wali menikahi anak yatim yang menjadi tanggungjawabnya jika ia sudah baligh dan berlaku adil.

f. Ayat ini menjadi dalil diperbolehkannya menikah sampai empat istri dan haram hukumnya melebihi empat.

g. Imam Malik, Dawud al-Zahiri dan al-Thabari menjadikan ayat ini sebagai syari'at menikah empat perempuan merdeka ataupun budak dengan kesetaraan yang sama. Berbeda dengan pendapatnya mereka, imam alSyafi'i dan Abu Hanifah menyatakan bahwa tidak boleh menikahi perempuan budak lebih dari dua sebagaimana kesepakatan para sahabat Nabi akan hal itu. Hal itu melihat atsar dari Ibnu Umar yang berbunyi:

${ }^{27}$ Hadis nomor 1969 riwayat Abu bakr bin Abi Shaibah, Waki', Hammam, Qatadah, al-Nadr bin Anas, Bashir bin Nahik, Abu Hurairah. lihat Ibnu Majah, Sunan Ibnu Majah, (Kairo: Dar al-Risalah al'Alamiyyah, 2009), jld. 3, 143.

${ }^{28}$ Wahbah al-Zuhaili, Al-Tafsir al-Munir fì al-'Aqidah wa al-Shari'ah wa al-Manhaj, jld. 4, 236. 
Tafsir Wahbah Al-Z Uhaili Analisis Pendekatan, Metodologi, Dan Corak Tafsir Al-Munir Terhadap Ayat Poligami (Mokhamad Sukron)

$$
\text { عن ابن عمر: أيّما عبد تزوّج بغير إذن مولاه فهو عاهر }
$$

Dari Ibnu Umar: "mana saja hamba sahaya menikah tanpa izin tuannya maka ia dikatakan pezina." 29

Para ulama berbeda pendapat tentang seseorang menikah lebih dari empat. Imam al-Syafi'i dan Abu Thur berpendapat bahwa laki-laki tersebut dikenai $\mathrm{h}$ \}ad jika tahu akan tidak boleh melebihi empat istri. AlZuhri berpendapat bahwa orang tersebut harus dirajam jika ia tahu akan hal tersebut, jika tidak maka cukup dih \}ad cambuk, maharnya tetap milik perempuan dan harus pisah. Abu Hanifah berpendapat bahwa tidak had bagi semuanya. Sedangkan Abu Yusuf dan Muhammad berpendapat orang tersebut dihad terkait pernikahan terlarang dan tidak dihad jika selain itu seperti menikahi perempuan majusi atau istri kelima dalam akad saja atau menikah mut'ah (kontrak), menikah tanpa saksi ataupun budak perempuan menikah tanpa seizin tuannya. ${ }^{30}$

h. Menikah dengan satu istri adalah wajib hukumnya jika takut berbuat zalim.

2. Terkait dengan ayat wa atu al-nisa'a saduqatihinna

a. Mahar adalah wajib diberikan kepada istri karena persenggamaan tidak halal kecuali dengan adanya mahar baik disebutkan dalam akad maupun tidak disebutkan.

b. Tanazul 'an al-Mahri (merelakan atau memberikan mahar) bagi seorang istri kepada suami hukumnya boleh.

c. Begitu halnya bagi suami boleh-boleh saja menerima pemberian mahar dari sang istri.

d. Pernyataan mahar di tempat sepi atau tanpa sepengetahuan banyak orang hukumnya adalah sah.

\section{Hikmah Dibalik Ayat Poligami}

Secara normalnya adalah seorang laki-laki memiliki istri satu, dan itu merupakan hal yang mulia dan utama. Namun Islam membolehkan poligami karena ada keadaan darurat ataupun kebutuhan mendesak dengan memberikan batasanbatasan seperti memiliki kemampuan untuk menafkahi, berlaku adil terhadap seluruh istri, interaksi yang baik. Kebolehan poligami, menurut al-Zuhaili, menjadi boleh atau bahkan dianjurkan karena ada beberapa hal di antaranya:

1. Istri mengalami kemandulan. Secara fitrah, manusia menginginkan keturunan untuk melanjutkan perjuangannya maka ketika istri mengalami kemandulan

${ }^{29}$ Wahbah al-Zuhaili, Al-Tafsir al-Munir fî al-'Aqidah wa al-Shari'ah wa al-Manhaj, jld. 4, 239. Lihat juga Abu Bakr Abdullah bin Abi Shaibah, al-Kitab al-Musanaf fi al-Ahadith wa al-Atsar, (Riyad: Maktabah al-Rushd, 1409 H), jld. 3, 534.

${ }^{30}$ Ibid, 240. 
apakah harus dicerai atau poligami? Tentu yang lebih akhaf al-dararain (resiko lebih ringan dari dua mudarat adalah poligami namun perlu diperhatikan halhal dalam poligami.

2. Jika suatu negara jumlah penduduknya mayoritas perempuan sedangkan lakilaki adalah minoritas maka yang paling utama adalah poligami demi menyelamatkan mereka dari perzinaan ataupun perselingkuhan.

3. Keadaan seksualitas, di mana seorang laki-laki masih dalam keadaan prima sedangkan perempuan sudah mengalami menopause atau seorang laki-laki merupakan hypersex maka perlu poligami. ${ }^{31}$ Adapun pada sisi praksisnya, banyak masyarakat muslim tidak mengindahkan batasan-batasan dalam poligami. Kebanyakan mereka hanya berdasarkan nafsu belaka. Jika demikian apa bedanya dengan kebudayaan Barat?

\section{Alasan Poligami Rasulullah Saw}

Nabi saw tidak pernah melakukan poligami sampai dengan sembilan istri hanya karena menuruti nafsu atau birahi belaka. Beliau hanya memiliki satu istri, yaitu Khadijah. Namun setelah wafatnya Khadijah dan tujuan kemanusiaan dan masyarakat Islam maka beliau melakukan poligami. Nabi saw menikahi Zainab binti Jahsh untuk menunjukkan penolakan Islam terhadap tradisi adopsi anak masyarakat jahiliyah.

Nabi saw menikahi seseorang dikarenakan untuk tujuan menyebarkan agama Islam di antara suku-suku di Arab sehingga menjadikan jalinan menantu dan mertua, sebagaimana Nabi menikahi Juwairiyyah binti al-Harith maka spontanitas suku Banu alMustaliq masuk Islam. Poligaminya Nabi saw pada hakikatnya memiliki banyak faidahnya, yang paling penting adalah memberikan pelajaran bagi perempuan muslimah tentang hukum-hukum khusus terkait perempuan dan antara suami istri. ${ }^{32}$

\section{Penutup}

Pada akhirnya, menurut hemat penulis, Wahbah al-Zuhaili adalah ulama kontemporer yang berhasil memadukan tradisi klasik dengan tradisi kekinian. Beliau membuktikan dengan tafsir al-Munirnya bahwa tradisi klasik masih relevan dengan masa kontemporer. Beliau juga memberikan pelajaran bagi civitas akademika di seluruh dunia, terlebih akademis Muslim, bahwa sekontemporer apapun metode yang digunakan jangan melupakan tradisi klasik sekaligus dalam memberikan tafsiran dari ayat-ayat al-Qur'an betul-betul harus memperhatikan kebutuhan dan tingkatan ilmu masyarakatnya.

Selain itu, dalam konteks pembahasan poligami untuk masa kontemporer memang perlu diberikan pemahaman yang menyeluruh kepada masyarakat di berbagai kalangan ataupun tingkatan bahwa poligami yang disyari'atkan Islam bukanlan hal yang

\footnotetext{
243.

${ }^{31}$ Wahbah al-Zuhaili, Al-Tafsir al-Munir fì al- 'Aqidah wa al-Shari 'ah wa al-Manhaj, jld. 4, 242-

32 Ibid, 244.
} 
Tafsir Wahbah Al-Z Uhaili Analisis Pendekatan, Metodologi, Dan Corak Tafsir Al-Munir Terhadap Ayat Poligami (Mokhamad Sukron)

menakutkan bagi perempuan atau menjadi penghancur perasaannya melainkan merupakan bentuk penghormatan Islam terhadap perempuan. Sedangkan bagi kaum lelaki, poligami bukanlah alat legitimasi untuk melegalkan hawa nafsunya belaka melainkan sebagai bentuk rahmat bagi seluruh umat.

\section{Daftar Pustaka}

'Abd Halim Mahmud, Mani'. Metodologi Tafsir: Kajian Komprehensif Metode Para Ahli Tafsir, terj. Syahdianor dan Faisal Saleh. Jakarta: Raja Grafindo Persada, 2006.

Abdul Madjid, Zamakhsyari. Metodologi Penafsiran Ayat-Ayat Hukum Dalam Tafsir AlMunir. Jakarta: Disertasi Sekolah Pasca Sarjana Universitas Islam Negeri (UIN) Syarif Hidayatullah, 2009.

Abdullah bin Abi Shaibah, Abu Bakr. Al-Kitab al-Mus\}anaf fi al-Ahadith wa al-Athar. Riyad: Maktabah al-Rushd, $1409 \mathrm{H}$.

Al-Farmawi, 'Abd al-Hayy. Al-Bidayah fi al-Tafsir al-Maudu 'i. Kairo: al-Hadharah al'Arabiyah, 1977.

Alfatih Suryadilaga, Muhammad, dkk. Metodologi Ilmu Tafsir. Yogyakarta: Teras, 2010. Al-Sayyid al-Lahm, Badi'u. Wahbah al-Zuhaili: al-'Alim wa al-Faqih wa al Mufassir. Damaskus: Dâr al-Qalam, 2001.

Al-Syarqawi, Ahmad bin Muhammad. Manahij al-Mufassirin. Riyadh: Maktabat alRusyd, $1424 \mathrm{H}$.

Al-Zahrani, Ahmad bin 'Abdullah. Al-Tafsir al-Maudu'i li al-Qur'an al-Karim wa Namadziji minhu. Madinah: Universitas Islamiyah Madinah, $1413 \mathrm{H}$.

Al-Zuhaili, Wahbah. Al-Qur'an dan Paradigma Peradaban, terj. M. Thohir dkk. Yogyakarta: Dinamika, 1996. - Al-Tafsir al-Munir fî al-'Aqidah wa al-Shari'ah wa al-Manhaj.

Beirut: Dâr al-Fikr, 1991. Al-Tafsir al-Wasit. Damaskus: Dar al-Fikr, $1422 \mathrm{H}$.

Arif Ahmad Fa'ri', Muhammad. Manhaj Wahbah al-Zuhaili fi al-Tafsir li al-Qur'an alKarim: Tafsir al-Munir. Karya Thesis di Universitas Alu al-Bait, 1998.

Baihaki. Studi Tafsir al-Munir Karya Wahbah al-Zuhaili dan Contoh Penafsirannya tentang Pernikahan Beda Agama. Journal Analisis. Vol. XVI. No. 1. Juni 2016.

Husain al-Zahabi, Muhammad. Al-Tafsir wa al-Mufassirun. Kairo: Dar al-Hadith, 2005. Ibnu Majah. Sunan Ibnu Majah. Kairo: Dar al-Risalah al-'Alamiyyah, 2009.

Louis Ma'lûf. Kamus al-Munjid. Beirût: al-Maktabah al-Sharqiyyah, 1986.

Lutfi Fathullah, Ahmad. Al-Qur'an al-Hadi. Jakarta: Pusat Kajian Hadis, 2013.

Quraish Shihab, Muhammad. Membumikan al-Qur'an: Fungsi dan Peran Wahyu dalam Kehidupan Masyarakat. Bandung: Mizan, 1996.

Robinson. Islamic Historiography. Cambridge: Cambridge University Press, 2006. 